\title{
ÁTTEKINTÉS A MAGYAR TUDOMÁNYOS AKADÉMIA- MISKOLCI EGYETEM KÖZÖS ANYAGTUDOMÁNYI KUTATÓCSOPORTJÁNAK KUTATÁSAIRÓL
}

\section{AN OVERVIEWABOUT THE SCIENTIFIC WORK OF THE HUNGARYAN ACADEMY OF SCIENCES - MISKOLC UNIVERSITY JOINT MATERIALS SCIENCE RESEARCH GROUP}

\author{
Roósz András \\ Miskolci Egyetem, Müszaki Anyagtudományi Kar, Fémtani, Képlékenyalakitási és \\ Nanotechnológiai Intézet, 3515 Miskolc, Egyetemváros), \\ Telefon / Fax: +36 46565 111/1543, femrooszvuni-miskolc.hu
}

\begin{abstract}
The Hungarian Academy of Sciences and Miskolc University joint Materials Science Research group founded in 1996 dealt with many different interesting materials science problems. In this paper some most interesting of these are shown shortly.
\end{abstract}

Keywords: laser surface treating, amorphous alloys, nanocomposite, unidirectional solidification, melt stirring, phase transformation simulation, equilibrium phase diagram

\section{Összefoglalás}

Az 1996-ban alakult Magyar Tudományos Akadémia és a Miskolci Egyetem közös Anyagtudományi kutatócsoport számos érdekes anyagtudományi problémával foglalkozott az elmúlt 20 során. A cikkben ezek közül mutatunk be néhányat a legérdekesebbek közül röviden.

Kulcsszavak: Lézeres felületkezelés, amorf ötvözetek, nano kompozitok, irányított kristályosítás, olvadék keverés, fázis átalakulások szimulációja, egyensúlyi fázis diagramok

\section{Az Anyagtudományi Kutatócsoportról}

A Kutatócsoport 1996-ban alakult a Miskolci Egyetemen (ME) az Magyar Tudományos Akadémia (MTA) támogatásával pályázat útján. A kezdetben 3 főből álló Kutatócsoport jelenleg 10 kutatót és egy technikust foglalkoztat. A Kutatócsoport müködését (bérek anyagok, kisebb eszközök) az MTA biztosítja, az infrastruktúrát (kutató eszközök nagy része, hely, fütés, világítás, informatika) az ME bocsájtja ren- delkezésre térítésmentesen. A pályázatot kezdetben 3, majd öt évenként újra be kellett nyújtani. A Kutatócsoport most nyerte el a müködéséhez szükséges összeget újabb 5 évre.

A Kutatócsoport kezdetben a lézeres felületkezeléssel foglalkozott. Később jelentősen bővült a kutatói létszám ezzel együtt a kutatási terület is szélesedett. A következőkben a különböző területeken elért eredményekröl számolunk be röviden. 


\section{Kutatási eredmények}

\subsection{Lézeres felületkezelés}

Lézeres felületkezelés során a néhány $\mathrm{mm}$ mély felületi réteget lehet hökezelni, de elé nagy energia sürüség esetén meg is lehet olvasztani. Az 1. ábra mutatja az átolvasztott zóna geometriáját. $\mathrm{CO} 2$ lézerrel végeztünk felületi hőkezeléseket, átolvasztást (1. ábra), valamint porbefúvásos technológiával a megolvasztott rétegbe különbözö anyagokat vittünk be. Ólom hozzáadásával jó siklási tulajdonsággal bíró kitünő siklócsapágy felületet (2. ábra), különböző oxidok befújásával kopásálló réteget hoztunk létre (3. ábra).

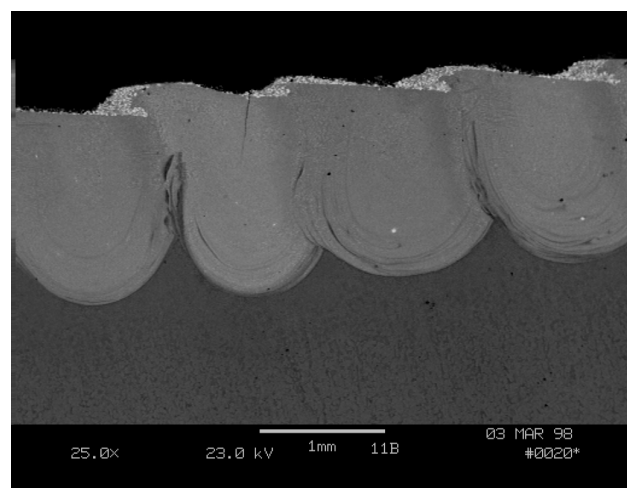

1. ábra. Melegalakitó szerszámacél átolvasztott felületi rétege

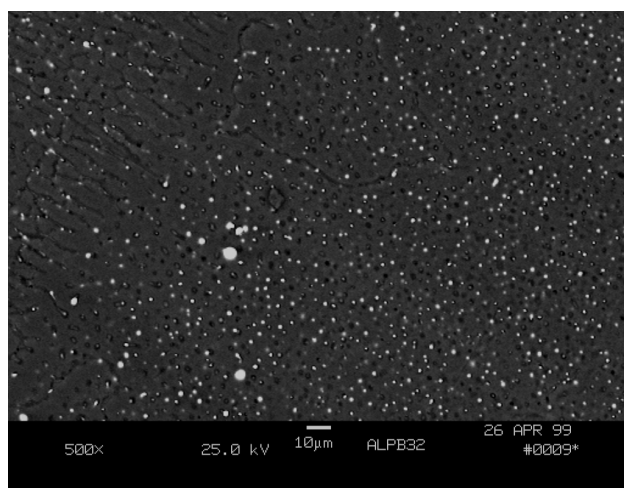

2. ábra. Ólomcseppek az alumínium

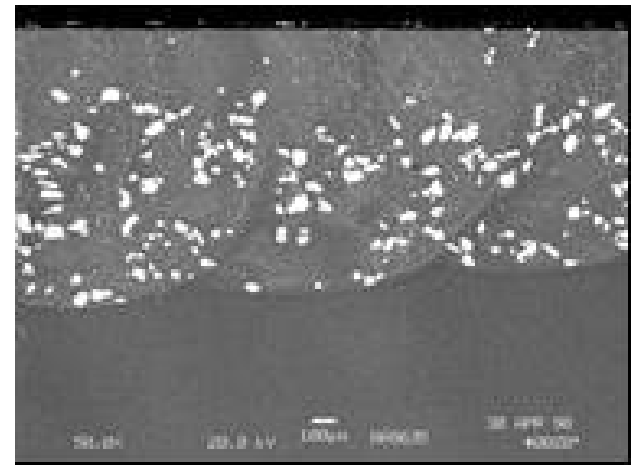

3. ábra. WC részecskék az átolvasztott rétegben

\subsection{Amorf ötvözetek}

A szilárd állapotú anyagaink két formában fordulnak elő. Lehetnek kristályosak és amorfok (4. ábra). Az amorf állapotú anyagokban az atomok között csak igen rövidtávú rend van, tulajdonképpen nagyon sok rácshibát (diszlokációt) tartalmazó kristály rácsként értelmezhetö. Ennek következtében különleges tulajdonságokkal bírnak (nagy szakító szilárdság, keménység stb).
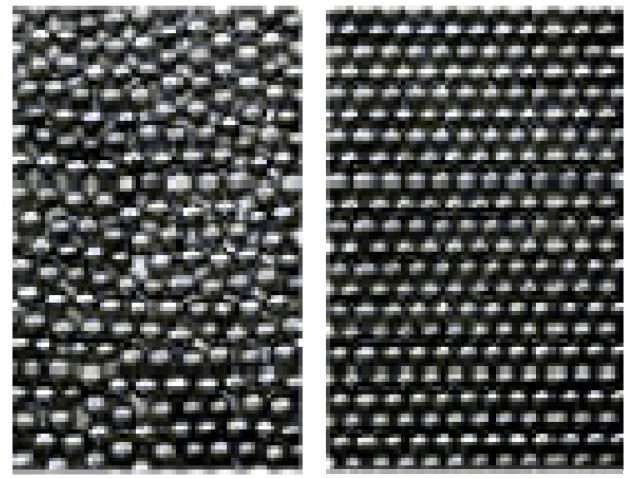

4. ábra. Amorf (a) és kristályos (b) szerkezet

Vékony (néhányszor $10 \mu \mathrm{m}$ ) vastag amorf ötvözetet már igen régen elö tudunk állítani különböző gyorshűtési technikákkal, ezek a szalagok, bár sok mindenre használhatók, szerkezeti anyagként nem jönnek szóba. A Kutatócsoport célja u.n. tömbi 
(bulk) amorf ötvözet előállítása, melynek vastagsága akár több tíz $\mathrm{mm}$ is lehet. Tömbi amorf ötvözetet két módon lehet elöállítani, gyors hütéssel (5. ábra) vagy őrléssel és az őrlemény kompaktálásával (6. ábra). A gyors hütés során el kell kerülni az átalakulásra (kristályosodásra) jellemző $\mathrm{C}$ görbe orrpontját. Ekkor túlhűlt olvadék jön létre.

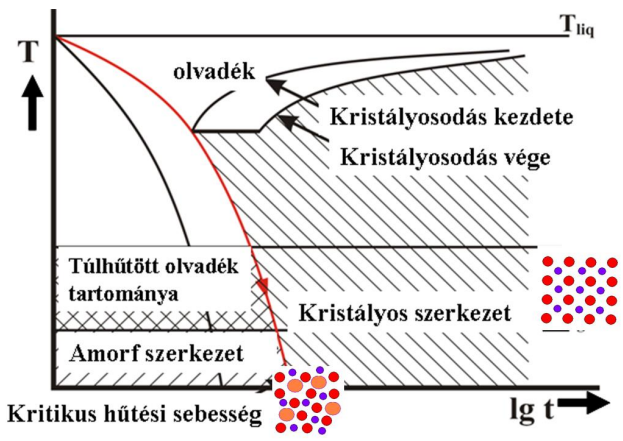

5. ábra. A túlhült olvadék keletkezése

A kristályosítási kísérleteket egy centrifugál öntő berendezésben, argon atmoszféra alatt végeztük. Ék alakú próbákat készítettünk különböző réz alapú ötvözetekből $(\mathrm{Cu}-$ Zr-Ag, Cu-Zr-Al, Cu-Zr-Ag-Al, Cu-Hf-Al, $\mathrm{Cu}-\mathrm{Hf}-\mathrm{Ti}$ ).

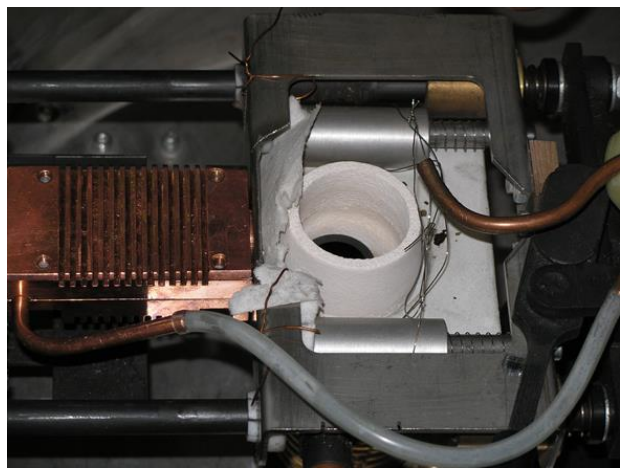

6. ábra. Centrifugál öntö berendezés

Az ékpróba csúcsa $\sim 20000 \mathrm{~K} / \mathrm{s}$, a töve $1000 \mathrm{~K} / \mathrm{s}$ sebességgel hült, így tanulmányozható volt a lehülési sebesség hatása egy próbán belül.

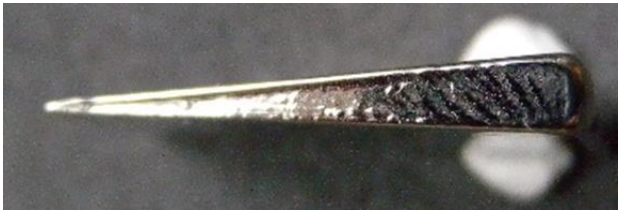

7. ábra. Az ékpróba

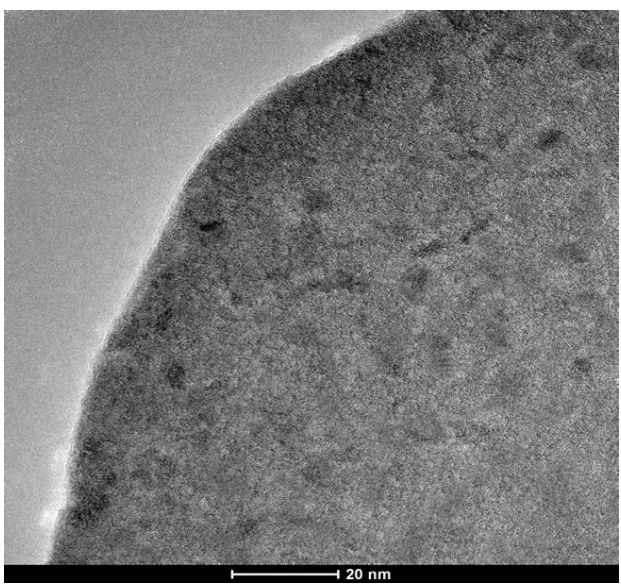

8. ábra. Az ékpróba nagy felbontású képe, a sötét foltok kristályos szerkezetüek

Ezzel a technológiával sikerült előállítanunk több mm vastag amorf ötvözetet. Az amorf ötvözet hőkezelésével amorf/nanokristályos kompozitot készítettünk.
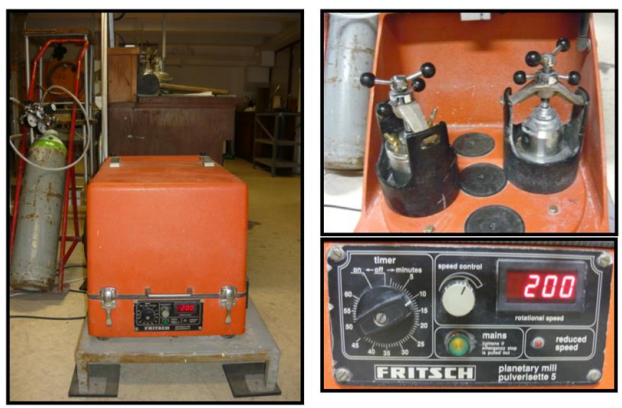

9. ábra. Az örlésnél használt golyósmalom

A másik lehetséges technológia során először golyós malomban (9. ábra) őröltük az amorfizálandó ötvözetet (10. ábra), majd sajtolás után az üvegesedési hőmér- 
séklet és a kristályosodási hőmérséklet közötti hőmérsékleten szintereltük. Így réz alapú nanokompozitot lehetett előállítani, amelynek a folyáshatára elérte az ötvözött acélét (2000 MPa).

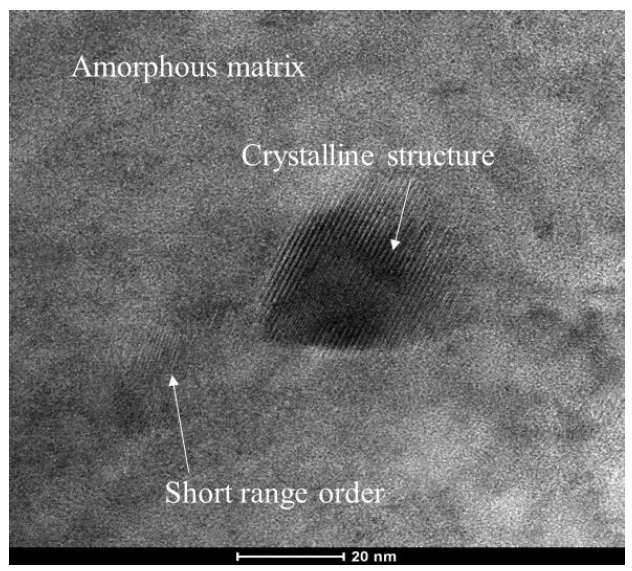

10. ábra. Amorf, rövid és hosszú távú rendet mutató rész az örleményben

\subsection{Az olvadék áramlás hatása a kris- tályos szerkezetre}

Az ipari kristályosítási technológiák során (formaöntés, acél folyamatos öntése, egykristály gyártás stb.) az olvadék mozog, áramlik kristályosodás közben. Az áramlást kiválthatja a folyékony fém beáramlása a formaüregbe, valamint a hőmérséklet és koncentráció különbségek miatt kialakuló sürüség különbség. Az olvadékáramlásnak lehet a gyártmány tulajdonsága szempontjából negatív hatása (makrodúsulás), de lehet pozitív hatása is, amikor az u.n. oszlopos mikroszerkezet az áramlás hatására u.n. ekviaxiális szerkezetté alakul. A Kutatócsoport 2000-ban csatlakozott egy az ESA által finanszírorozott nemzetközi kutatási programhoz (MICAST), majd 2014-ben egy másikhoz (CETSOL), melyekben 8 különböző országból 50 kutató dolgozik. A két projekt az áramlás kizárásával (a Nemzetközi Ürállomáson) és mágneses térrel forszírozott áramlás mellett vizsgálja az áramlás hatását a kialakuló mikroszerkezetre.

A Kutatócsoport saját tervek alapján épített két egyedülálló berendezést a vizsgálatokhoz. Mindkét berendezésben egyirányú hőelvonással kristályosítjuk a próbákat. Az egyik berendezésben forgó mágneses térrel (Rotation Magnetic Field, RMF, 11. ábra), a másikban vándorló mágneses térrel (Traveling Magnetic Field, TMF, 14. ábra) áramoltatjuk az olvadékot.

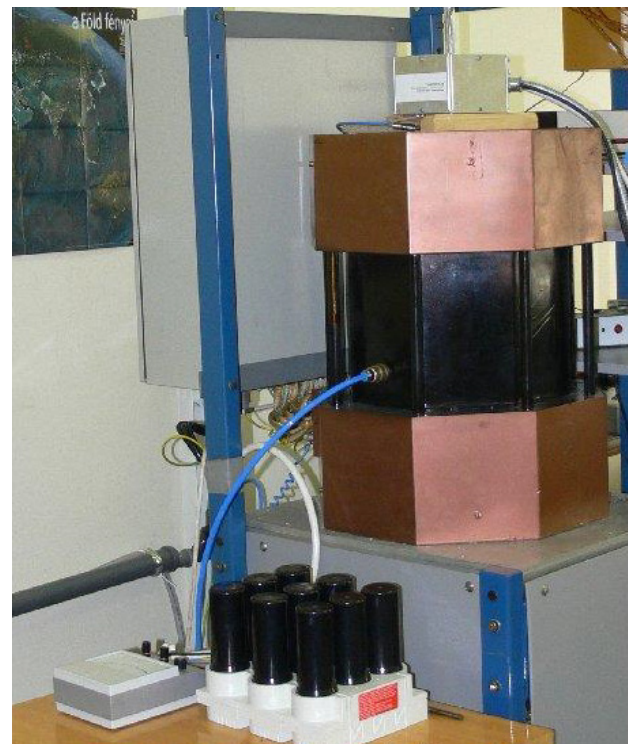

11. ábra. Kristályositó berendezés RMF induktorral

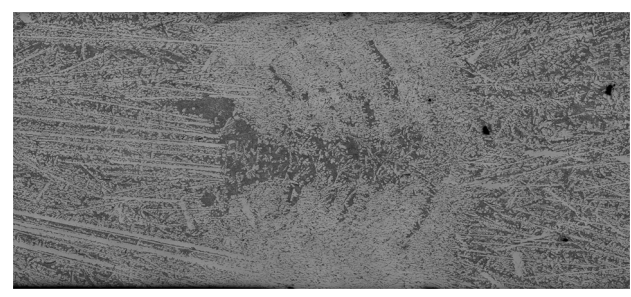

12. ábra. Átmenet a nem kevert (oszlopos) és kevert (ekviaxiális) rész között (RMF) 

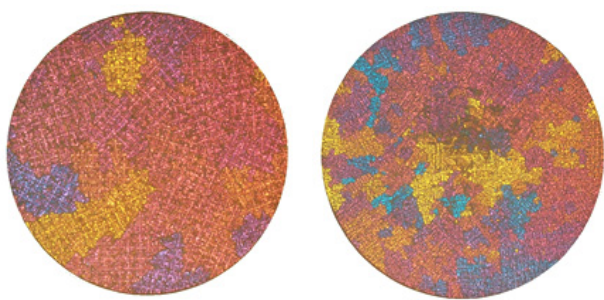

13. ábra. Az olvadék áramoltatása nélkül (a) és áramoltatásával kristályositott Al$1 t \% \mathrm{Fe}-7 t \%$ Si ötvözet szövetképe

A $8 \mathrm{~mm}$ átmérőjü és $100 \mathrm{~mm}$ hosszú próbák felét az olvadék áramoltatása nélkül, majd másik felét az olvadék áramoltatása közben kristályosítottuk. Ennek eredményeként az oszlopos dendrites szerkezet ekviaxiálissá vált nagy mágneses tér esetében a próba közepén dúsult az $\mathrm{Si}$ és az Fe, kialakult az u.n. karácsonyfa szerkezet (12. ábra). A szemcseszerkezet jelentősen finomodott (13. ábra).

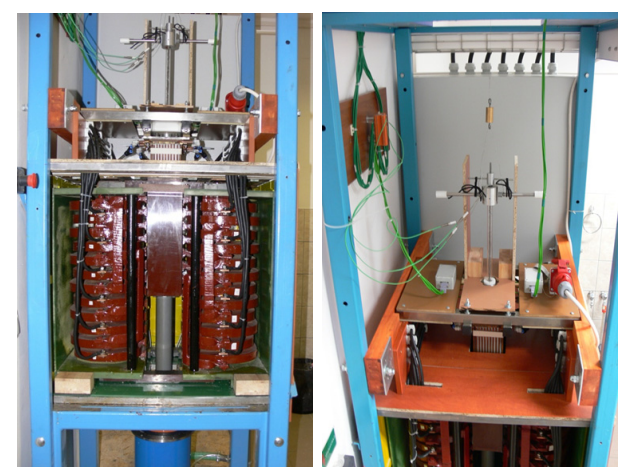

14. ábra. Kristályositó berendezés TMF induktorral

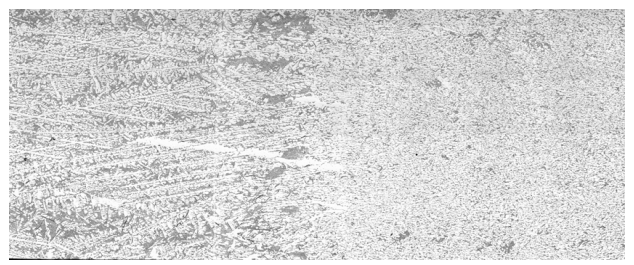

15. ábra. Átmenet a nem kevert (oszlopos) és kevert (ekviaxiális) rész között (TMF)
A TMF-el (14. ábra) kevert próbák szövetszerkezete a keverés bekapcsolását követően az RMF-es keveréshez hasonlóan oszlopos szerkezetből ekviaxiálissá vált, a dendrites szerkezet nagymértékben finomodott. Ez esetben jelentős makrodúsulás nem alakult ki (15. ábra). A gyakorlatban ezzel a keverési móddal lehet finomítani a szövetszerkezetet.

\subsection{Az acél ausztenitesedésének nu- merikus szimulációja}

Az acélokban lezajló átalakulási folyamatok szimulációja jelentős segítséget nyujthat a hőkezelési folyamatok tervezéséhez. A folyamatokat lehet analítikus formában (egyenletekkel) szimulálni (pl. az átalakult térfogathányadot a jól ismert Avrami egyenlettel), vagy látványosan, filmszerüen numerikus eljárásokkal.
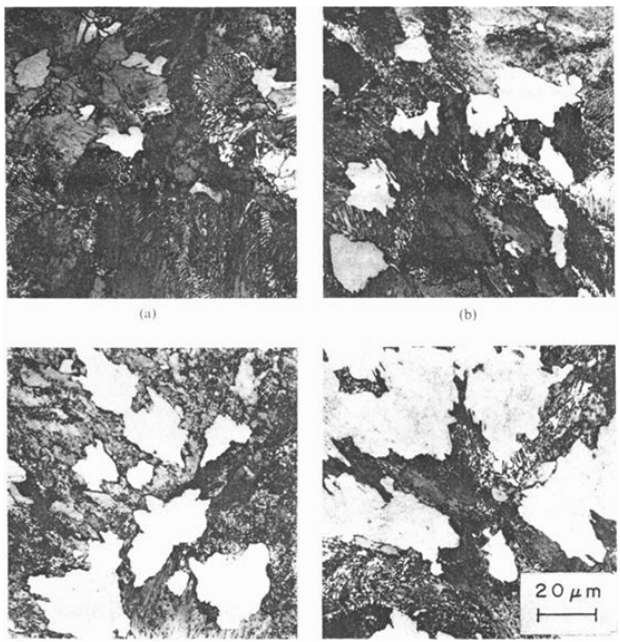

16. ábra. Perlites acél ausztenitesedése

A 16. ábrán egy tisztán perlitet (ferrit+cementi) tartalmazó acél ausztenitesedését mutatjuk be négy köztes állapotban. A világos területek a hőkezelés hőmérsékletén ausztenit szemcsék voltak, az edzés során természetesen martenzitté alakultak. 
A csírák a perlit kolóniák határán keletkeztek (17. ábra), majd növekedtek.

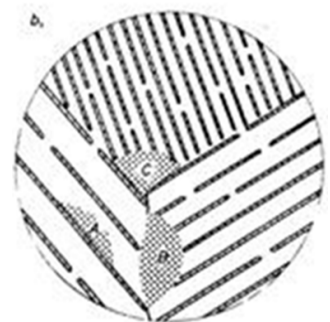

17. ábra. Csíraképzödés a perlit-kolóniák határán

A szimuláció numerikus eljárásokkal, összekapcsolva a diffúzió számítására használt Véges Differencia (VD) módszert a Cella Automata (CA) eljárással, az átalakulási folyamat filmszerően is bemutatható. A 18.a. ábra egy perlit/ferrites acél, a 18.b. ábra egy tisztán perlites acél egy kolóniájának ausztenitesedését szemlélteti. Ez utóbbi esetben az ausztenit át tud nőni a cementit lemezek között azok töredezettsége miatt.
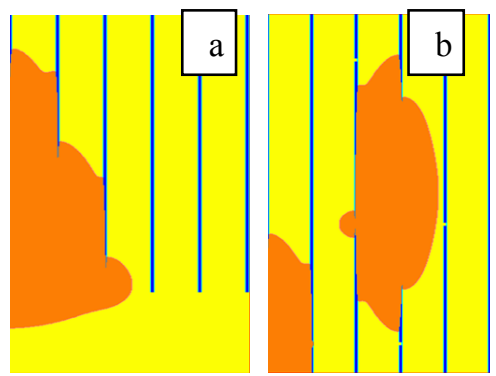

18. ábra. Perlit/ferrites és tisztán perlites acél egy kolóniájának ausztenitesedése $V D+C A$ módszerrel számítva.

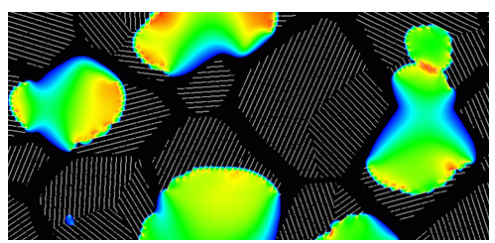

19. ábra. Perlit/ferrites acél ausztenitesedése
A 19. ábrán egy perlit/ferrites acél kis részletének (több kolóniának) az ausztenitesedése látható az említett VD+CA módszerrel számítva.

\subsection{Egyensúlyi fázisdiagram vonalai- nak (felületeinek) számítása (ESTPHAD módszer)}

Az egyensúlyi-fázisdiagramok vonalainak (felületeinek) számszerü ismerete alapvető feltétele bármely átalakulási szimulációnak. A Kutatócsoport egy, termodinamikai alapokra támaszkodó, egyszerü számítási eljáárást dolgozott ki ennek a feladatnak a megoldására.

Bármely vonalat vagy felületet egy eygszerü hatványfüggvénnyel lehet megadni. Alábbiakban egy likvidusz felület egyenlete, látható ( $\mathrm{T}_{\mathrm{L}}$ likvidusz hőmérséklet, $\mathrm{X}_{\mathrm{B}}$ a koncentráció):

$T_{L}=T_{A} /\left(1+\sum_{i=0}^{l} A l_{A B}(i)\left(X_{B}^{l}\right)^{i}\right)=T_{A} /\left(1+F l_{A B}\left(X_{B}^{l}\right)\right)$

A 20. ábrán az Al-Cu-Si ötvözetrendszernek az ESTPHAD rendszerrel számított (pontok) és mért (folytonos vonal) izotermái láthatók.

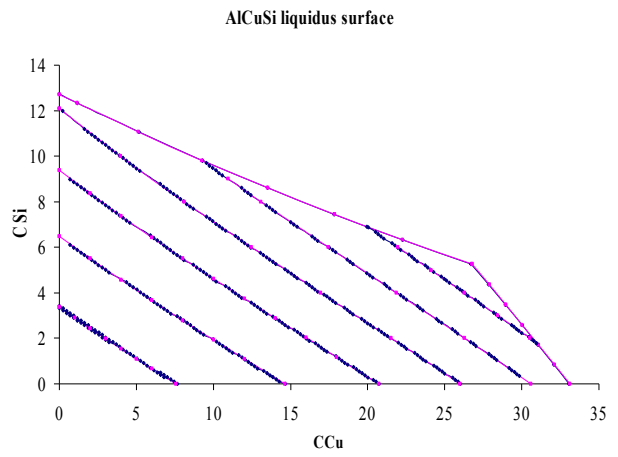

20. ábra. $A z A l-C u$-Si ötvözetrendszer likvidusz felülete alumínium sarkának mért és számított izotermái 